\title{
Entrevista com Michel Pialoux e Stéphane Beaud*
}

\author{
Por Vera Telles, Stéphane Beaud, Sergio Miceli, \\ Afrânio Garcia, Jean-Pierre Faguer, Marco A. Santana, \\ Roberto Grün e Marie-Claude Muñoz
}

0 " mundo operário sem classe operária" : diferença dos tempos sociais e condiç̧ão operária

Vera Telles - No artigo "Rebeliões urbanas e a desestruturação das classes populares" publicado neste número da revista Tempo Social, vocês chamam a atenção para uma história mai s longa pertinente ao processo de desestruturação da classe operária que se inicia nos anos de 1980. É a questão inscrita na proposição de que, hoje, trata-sede um "mundo operário sem classe operária" ou um "mundo operário depois da classe operária".

Afrên IO GaRCIA - É importanteenfatizar queM ichel estéphanefizeram uma etnografia do mundo operário entre 1983 e 1988. Q uer dizer, uma etnografia contemporânea desse processo de desestruturação da classe operária. E isso éimportante também para chamar a atenção para o fato de que não se trata tão simplesmente do regi stro defatos objetivos. N essa etnografia está em jogo o ol har do sociólogo, um modo detratar ascoisas, de colocar as questões em evidência, na contracorrente deum momento no qual o mundo intelectual francêshavia abandonado a referência à classe operária. Q uando $M$ ichel lança a pesquisa em 1983 sobrea Peugeot, em Sochaux, era justamenteo momento em queo tema do "adeusao proletariado" 1 iria dar o tom em todo o debate político eintelectual na França.
*Entrevistarealizadaem 9 dejaneiro de2006 na École des $H$ autes Étudesen Sciences Sociales, Paris. Em razão decompromissos acadêmicos, Stéphane Beaud só estevepresentenaprimera parteda entrevista.

1. Referência ao livro de AndréG orzquemarcou o debate no início dos anos de 1980. Ver André Gorz, Adieux au proléariat: au delà du socialisme, Paris, Seuil, 1981 (trad. bras: Adeus ao proletariado: para além do socialismo, Rio de Janeiro, Forense, 1982). 
Pialoux - N ós falamos da desestruturação da classe operária que se inicia nos anos de 1980. Essa é uma realidade e uma temática tratada em nossos livros. M as não há apenas isso, e nós não somos tão simplesmente teóricos da desestruturação da classe operária. Pois existe também o tema da resistência operária, ea lógica da desestruturação, mas também a lógica de resistências multiformes que nem sempre são muito claras, que não têm uma direção definida, com as quais os sindicatos não sabem lidar, que podem ser até mesmo um pouco disparatadas. Seria preciso pensar tudo isso em conjunto e tentar compreender a relação entre essa lógica de resistência e as formas de violência que surgiram nesses anos. Foi justamente essa a questão que discutimos em nosso último livro, Violences urbaines, violence sociale (2003), escrito logo depois de uma "rebelião urbana" que eclode na região de Sochaux-M ontbéliard em julho de 2000. N esse livro apresentamos um quadro desse processo de desestruturação da classe operária e analisamos a revolta em Sochaux em relação a ele. É um quadro nada otimista e chegamos a enunciar explicitamente a possibilidade de uma situação como essa que explodiu em 2005. N esselivro, falamos da desestruturação dessegrupo antes chamado "classe operária", mas colocamos uma ênfase maior em formas de resistência que ainda não haviam sido analisadas e que não são muito compatíveis entre si: de um lado, o modo como os mais velhos tentam contornar a situação, as modalidades de rejeição da fábrica, uma rejeição por vezes bastante violenta misturada com rancor e desconcerto; de outro lado, o modo como os jovens reagem, inclusive ateando fogo nos carros. São dimen sões da condição operária que devem ser anal isadas conjuntamente, é preciso pensá-las em relação às novas formas de dominação e de exploração que surgiram no correr desses anos todos, que desestabilizaram antigas formas de resistência, que deixaram os militantes inteiramente desconcerta-

2. Esseéo tematratado por Pialoux em doisca pítulos do livro A misé ria do mundo, organiza do por Bourdieu (Rio de Janeiro, Vozes, 1997): "O velho operário e a fábrica" (pp. 321-338) e "A perturbação do delegado sindical" (pp. 371-388). dos², com as quais os sindicatos não sabem lidar, em relação às quais não conseguem definir uma estratégia.

BEAUD - Em relação à rebelião urbana do outono de 2005, decidimos fazer esse texto justamente porque havíamos escrito o Violences urbaines, violence sociale achamos que havia no livro questões que poderiam ajudar a compreender melhor os acontecimentos atuais. É possível analisar essas revoltas como resultantes de certo número de processos sociais que construíram essa geração de filhos de operários, pois são filhos de operários que estavam nas ruas. Como disse o Afrânio, a pesquisa etnográfica foi contemporânea desse processo de desestruturação da classe operária, mas não é possível se esquivar da questão das formas de resistência e das suas diferenças no tempo. 
Q uando se ouvem os relatos dos militantes no início dos anos de 1980 quando se considera o que foi a greve de 1981 e de 1989 na PeugeotSochaux e quando se vêo que aconteceu na década de 1990, há uma enorme diferença nas modalidades da resistência. Esse é um ponto importante que seria preciso enfatizar.

Vera Telles - Talvez esse possa ser o ponto de partida, fazer essa marcação da diferença dostempos.

BEAUD - Antes de tudo, é preciso lembrar que esse trabalho foi desenvolvido a dois, que no início foi $M$ ichel quem levou a pesquisa, foi ele quem a lançou no início dos anos de 1980. Portanto, é importante voltar ao trabaIho que ele desenvolveu sobre o militantismo operário, voltar à sua relação com o campo, ao trabal ho desenvolvido junto com Christian Corouge 3 . A pesquisa em Sochaux começa aí, com M ichel e Corouge, e eu só chego depois, em 1988. Portanto, é uma pesquisa de longa duração sobre o "grupo operário" e as lógicas de desestruturação que irão afetar seus modos de existência4. Para que a discussão seja de fato interessante, não acho que seja o caso de refazer a gênese de nossa pesquisa, mas demarcar al guns pontos de passagem.

Q uando eu estava em Sochaux, entre 1988 e 1996, era um momento em que não ocorriam demissões abertas, mas havia uma baixa regular do emprego, a intensificação do trabalho, formas novas de exploração. Porém, quando encontrávamos tanto os militantes como os operários de base, eles estavam muito abertos à discussão. A pesquisa foi então desenvolvida em boas condições etnográficas. Alguns anos mais tarde, quando voltamos ao campo para uma pesquisa nas PM Es [pequenas e médias empresas] da Technoland ${ }^{5}$, lembro bem que o que mais me chocou foi o fato de que era muito mais difícil conseguir se relacionar com os operários e as operárias. Com exceção de um pequeno núcleo sindical, a maior parte dos jovens, e mesmo os não tão jovens que trabal havam nessas empresas, não era mais abordável pelo sociólogo. Eles se esquivavam, fugiam dos encontros marcados, não tinham vontade de falar. Antes, em Sochaux, havia intermediários quetornavam possível encontrar as pessoas no local. H oje, eles estão dispersos no espaço, têm horários complicados, têm jornadas diferentes, e, além disso, não existem mais os representantes sindicais. $\mathrm{N}$ a época eu estava fazendo uma pesqui sa sobre operários com baccalaureat ${ }^{6}$ quetrabal havam nessas PM Es, e não foi nada fácil conseguir as entrevistas. Q uer dizer, em poucos
3. 0 perário em Sochaux desde 1968, militantee, naépoca, delegado sindical da CGT (Confederação G eral do Trabar Iho). Adiantena entrevista, Pialoux iráfalar de seu encontro com Corougeeo início da pesquisa em 1983.

4. Sobreaorigem dapesquisa, abordagens e questões orientadoras, ver Stéphane Beaud e M ichel Pialoux, "Etnografia operária esociologia: a composição de uma equipe", em Pierre Encrevé e Rose-M arie Lagrave (coords.), Trabalhar com Bourdieu (Rio de Janeiro, Bertrand Brasil, 2005, pp. 113120).

5. Technoland é uma vastazonaindustrial que seformou no correr dos anos de 1990 nas proximidades deSochaux, concentrando cerca de duascentenas de peque nas e médias empresas subcontratadas para 0 fornecimento depeçase equipamentos antes produzidos pela própria fábrica. N essas empresas, as condições detrabalho são especialmenteduras, os trabalhadoresganham salário mínimo e são considerados não-qualificados independentementedo ní- 
vel deformação. $N$ asua grandemaioria, são jovens, entre 22 e 35 anos, com relações pre cárias de trabalho: são temporáriosou possuem oschamados contratos de duração determinada. Ver Violencesurbaines, violencesociale, pp. 127-128.

6.0 baccalaureat, ou bac, éo exameaplicado após a conclusão do secundário equecredencia os estudantes a seguir 0 ensino universitário. Confere um diploma quecorrespondeao primeiro estágio universitário. A pesquisa a que Beaud se refere dará origem ao seu livro $80 \%$ au bac... \& après? Lesenfants de la démocratisation scolaire(Paris, La Découverte, 2002). anos, as condições de acesso ao campo mudaram fundamentalmente. Era mais difícil em função das condições objetivas e, depois, nos anos de 1990, os operários bacheliers tinham vergonha de dizer que eram operários. Eles não queriam se apresentar como operários. Antes, eu me lembro daquelas entrevistas com operários não qualificados, com operários profissionais, com militantes, em que todos eles nos recebiam em suas casas durante horas e assumiam um discurso ao mesmo tempo operário e militante.

AfrânIo GarcIA - Então seria interessantevocêfalar um pouco da conjuntura queencontrou quando chegou a Sochaux em 1983.

Pialoux - É importante voltar um pouco atrás e lembrar que, antes disso, os anos entre 1967 a 1973 foram de apogeu da classe operária e do movimento operário. 0 correram os fatos de 1968 e uma greve geral que a Europa até então não havia conhecido igual: dez milhões de operários pararam. 0 movimento operário tinha uma grande vitalidade e era estruturado por oposições entreo PC [Partido C omunista] e os "esquerdistas", entrea CG T [C onfederação G eral do Trabalho] e a CFDT [C onfederação Francesa D emocrática do Trabalho]. 0 início da década de 1970 é, talvez, o momento em que o taylorismo atinge seu ápice. A proporção de operários na população ativa francesa era muito alta e grande parte deles era sindicalizada. Isso muda a partir de 1975, quando, em termos econômicos, entramos na fase da "crise". É o momento em que surgem as teorias sobre o esgotamento da organização fordista do trabalho. A partir daí, a crise econômica se aprofunda, o desemprego aumenta, as taxas de sindicalização diminuem, as lutas nas empresas também diminuem. A desmoralização do mundo operário jáse torna perceptível a partir dessemomento. Em 1981, temos a chegada da esquerda ao poder com M itterrand, as esperanças eram muitas ehavia a expectativa de uma política capaz de reverter as lógicas econômicas que então já predominavam. M asisso não aconteceu. Q uando cheguei aSochaux em 1983, o desencantamento já tomava conta do meio operário. N esse momento se desencadeia uma espiral de desmoralização que não iria se interromper equese traduziria em uma dessindicalização muito rápida. Além disso, no meio intelectual a questão operária sai do foco das atenções. 0 tema principal na época éo "fim das utopias" e o lema é "deixar de acreditar nas utopias, voltar ao real". É o momento da "reabilitação da empresa", a problemática da "modernização" e das inovações tecnológicas entra em circulação e o tema "classe operária" passa a ser visto como al go obsoleto. H a- 
via, no mundo intelectual, uma forma muito peculiar de desdramatizar os conflitos e negar a realidade operária.

BEAUD - U ma pesquisa como a que M ichel fez em Sochaux permite justamente perceber uma condição operária que se estruturava com base em oposições e tensões muito fortes. Podese dizer que é a oposição capitaltrabalho, mas é preciso ver como isso iria se traduzir no chão de fábrica. H avia operários superexplorados, militantes perseguidos, colocados em "postos de punição". 0 vocabulário operário carrega fortemente essa história que, hoje, cai no esquecimento. Eram os anos de 1980. 0 livro deBoltanski e C hiappello [Le nouvel esprit du capitalisme, 1999] nos mostra: é verdade que houve uma espécie de contra-revolução, uma retomada ideológica do patronato. $M$ as nos locais de trabal ho foram utilizadas técnicas muito violentas para liquidar esse contrapoder operário que havia surgido depois de 1968. Q uando M ichel chega a Sochaux, em 1983, a lembrança desses tempos heróicos ou difíceis estava muito presente. Estava presente na história dosmilitantes queforam atingidos, e aparecia deforma muito viva nos seus relatos deentão. $\mathrm{H}$ avia, por exemplo, o caso de um delegado sindical que se suicidou em 1979, de outro que se divorciou porque toda a situação terminou por afetar a família etc. É importante colocar as coisas nesse contexto.

Para voltar à questão levantada por Afrânio, diria que a cronologia do sociólogo não éa mesma do historiador. Para o sociólogo, o interessante são os tempos sociais, o fato de que eles são diferentes. Seria preciso fazer a história das gerações, a história dos $0 \mathrm{~S}$ [ouvrier spécialisé] e dos OP [ouvrier professionnel] ${ }^{7}$. 0 que me parece interessante no caso da Peugeot é justamente essa sucessão das gerações $0 \mathrm{~S}$ e O P. N ós trabal hamos sobreisso, mas há ainda mais coisas a serem escritas.

PIALOUX - D e fato, essa clivagem entre os O S e os O P é central nesse momento. $N$ ão se trata de uma oposição como a que poderia existir no mundo intelectual, por exemplo entre comunistas e "esquerdistas". Era outra coisa, algo de profundo, que tinha a ver com diferenças nas formas de viver a condição operária, diferenças na relação com o mundo social. H avia um antigo militantismo operário que era o dos operários profissionais e que se enraizava fundo na história francesa. Eram pessoas ligadas ao PCF eà CGT, uma gente que tinha um agudo sentido do que era a classe operária, a consciência operária, a dignidade operária. Tinham a capacidade de fazer um discurso sobre a condição operária, sobre a necessidade de defender os valores operários da solidariedade, que era um discurso inscrito em uma tradição bem francesa. Q uanto aos OS, eram na sua maioria de origem
7. O s ouvriersspéciali sés (operários especializados) correspondem aos trabalhadoresnão-qualificados. Os ouvriers professionnels(operários profissionais) são operá rios qualificados que cursaram uma escola de ensino técnico para a obtenção deum CAP Certificat d'aptitude professionnelle (certificado deaptidão profissional), ou um diploma técnico superior. 
camponesa, vindos de regiões diferentes da França, muito freqüentemente famílias católicas. Claro, também existiam os marroquinos, os argelinos, alguns turcos e os tunisianos. $M$ as eles eram minoria, não mais do que $15 \%$, e não contavam muito no jogo político.

A clivagem entre $\mathrm{OS}$ e O P era muito forte. $\mathrm{N}$ as primeiras entrevistas que fiz com Corouge, entre 1983 e 1986, essa questão voltava o tempo todo. Entre os $\mathrm{O} S$ havia um protesto surdo contra o desprezo com o qual eram tratados pel os O P, eles se ressentiam da sua "condescendência" - era a palavra freqüentemente empregada na época - , criticavam a recusa dos OP em verificar o que ocorria realmente nos postos de trabal ho $O S$. $D$ aí a insistência de muitos desses militantes sobre as condições de trabal ho, não tanto quanto aos salários. M as há outro lado sobre o qual também falamos longamente no Retour. O s O P também apareciam como uma referência positiva, de que era possível seguir uma carreira profissional, de que era possível se tornar um O P ou então um chefe de equipe, um contramestre. $\mathrm{H}$ avia a possi bilidade real de evoluir, era possível passar pelos testes, passar pelas experiências, obter um CAP e se tornar um "profissional" em uma fábrica como a Peugeot-Sochaux, que era a mai or na França e contava com o maior número de O P. Era uma carreira bastante organizada. A possi bilidade existia. Além disso, havia uma escola profissional que formava essa el ite operária. 0 fato é que havia uma mobilidade interna ao mundo operário, que se desenvolvia nos quadros de trajetórias operárias, no interior de uma cultura operária. N os anos de 1980, isso desaparece. A distância dos níveis de salário e de prestígio entre O $\mathrm{S}$ e OP foi muito reduzida. O s O P não desfrutam mais das vantagens e garantias de antes, as promoções deixam de existir, eles passam a sofrer um violento processo de desval orização dentro da fábrica. E, conforme a eletrônica foi se instalando, as antigas profissões desaparecem e os técnicos passam a ganhar importância na fábrica. Isso quer dizer que a clivagem entre O S e O P irá se atenuar e perder importância nos anos de 1990, não estará mais no centro da vida sindical, mesmo quando as antigas animosidades persistem. 0 fato é que, na década de 1970, os dirigentes da CGT e da CFD T eram todos OP. N os anos de 1990, são quase todos O S. N a CG T não há mais do que um antigo O P ou um técnico, todos os outros são $O S$.

AfRÂN IO G ARCIA - Vocês falam das oposiçõesinternas ao movimento operário: entre OP e OS, entre direções sindicais, entre jovens e vel hos. M as também se referem ao fato de que existia, apesar dessas clivagens, o sentimento de classe 
operária, al go queunificava, quefazia com quetodosse percebessem como parte de um mesmo mundo. Por onde passava esse sentimento de fazer parte de um mesmo mundo, um mundo operário, de uma classe operária?

Pialoux - As pesquisas realizadas nosanos de 1950 ou 1960 sobreconsciênciaoperária mostram queas pessoassedefiniam como "operários". A o responder à questão "em que classe você se enquadra?", respondiam: "O perário". Cerca de $50 \%$ ou $60 \%$ das pessoas das classes populares se percebiam como partedo mundo operário. A palavra "operário" eralargamenteassumida. N os anos de 1980 isso vai mudar, ela setornará uma palavra que soa mal, sobretudo entre osjovens o termo "operário" ganha um sentido muito negativo, de desqualificação, vem carregado de desprezo, derejeição. N a fábrica, secomeçaafalar em "operadores" ou "agentes defabricação", e o processo iráseacelerar rapidamentea ponto de os jovens atual menterecusarem a palavra operário. H átrinta anosnão havia a distinção entreo operário e o empregado, por exemplo, de transportes. Eram todos operários, todos se viam como operários. "O perador" éuma palavra da década de 1990. Essa é uma questão importante, o uso das palavras diz muito da relação com o mundo social ${ }^{8}$. BEAUD - Há isso e mais do que isso. Existe um lado que poucas vezes é levado em conta. Chegamos a discutir isso juntos. Q uando eu me lembro como era Sochaux quando cheguei lá da primeira vez e comparo com hoje em dia, quanta diferença! Em 1988, Sochaux não era a mesma coisa, claro, que Zola descreve, mas era o mundo operário, um lugar cinza, sombrio, tristonho. $N$ a paisagem, a imensidão da fábrica e a cidade de $M$ ontbéliard, que era suja, muito malcuidada. Agora, vinte anos depois, tudo foi refeito, toda a cidade parece reconstruída. As fachadas foram completamente revestidas. Seria possível fazer uma etnografia das paisagens. Antes, tinha um café operário a cada dez metros ao longo da avenida. Só sobraram dois. N o lugar dos cafés, vemos as empresas de trabalho temporário.

PIALOUX - É preciso também levar em conta o que estava acontecendo no conjunto da sociedade, sobretudo as mudanças no sistema de ensino. Passa a existir um fortíssimo estímulo ao chamado ensino geral eà preparação para o ensino superior, em detrimento do ensino profissional voltado às qualificações operárias, o que está ligado também a certa percepção das mudanças tecnológicas. A partir de certo momento, quem não tinha um bac passava a ser considerado incapaz. $E$, para quem obtém um bac, o que antes remetia ao mundo operário én egado, como que anulado. I sso contribuiu enormemente para desval orizar a palavra e a própria realidade operá-
8. Essa éa questão discutida no artigo dePialoux e Beaud, "C ette casse deliberée des solidarités militantes" (Le M onde D iplomatique, janeiro de 2000). 
ria. 0 "operário" passa a significar al go muito desvalorizado, o que era bastante visível no final dos anos de 1980 em Sochaux. E os efeitos sobre todo o universo das representações operárias éal go importantea ser considerado. Junto com as transformações no plano do trabalho, são processos que desestabilizaram profundamente as formas de identificação operária, o modo como os operários percebem a si próprios, como se relacionam com o mundo social. Por isso achamos importante levar em conta os efeitos diretos e indiretos das mudanças no sistema escolar, coisa que muito raramente era considerada nas análises de sociólogos que privilegiavam apenas o universo da fábrica, sem ver o que estava acontecendo no conjunto da sociedade.

SeRgIO M ICELI - Como os sindicatos reagi ram a essas tranforormações dos anos de 1980 ?

PialouX - É importante ver o que aconteceu na fábrica entre 1980 e 1990. D esde 1979 não ocorriam mais contratações operárias. H avia, aliás, o plano defechar afábrica, como aconteceu com a Renault em Billancourt. D epois, resolveram fazer a renovação industrial lá mesmo. M as até 1988-1989, nada de contratações operárias, apenas contratações de técnicos e engenheiros. Entre 1984 e 1985 não chegou a acontecer demissões abertas. 0 que ocorreu, isso sim, foi o "incentivo" para os operários imigrantes voltarem a seus países de origem, em um plano impulsionado pelo Escritório $\mathrm{N}$ acional de Imigração. A empresa oferecia uma compensação monetária para "encorajar" marroquinos esobretudo argelinos a irem embora. $\mathrm{N}$ a época, 3 mil ou 4 mil operários retornaram e em muitas cidades houve uma diminuição sensível da população, como em Béthoncourt, que passou de 12 mil moradores para 9 mil. A pressão não foi pequena. Tenho depoimentos gravados de operários argelinos que contam que as formas de pressão eram fortes e muito duras. $\mathrm{H}$ avia ainda o desemprego tecnológico esemanas inteiras com redução das jornadas de trabalho. As lutas sindicais aconteciam em torno dessas questões, mas eram ações apenas defensivas. 0 fato é que era muito difícil organizar alguma forma de resistência.

Além disso, ocorreram as subcontratações ea entrada dos trabal hadores temporários. O s sindicatos protestaram, mas não puderam ou não souberam reagir. Eram rapazes de 20 anos que chegavam, encontravam os operários mais velhos, de 40 ou 50 anos, e achavam que eles, os mais velhos, pouco se importavam com a sua sorte. Estes, por sua vez, podiam até se sentir tocados pela situação dos temporários, sobretudo se tinham filhos 
dessa idade que estavam ou poderiam estar na mesma condição de trabal ho precário. M as não chegavam a definir uma estratégia para forçar a direção da empresa a alterar essa política. 0 fato éque, no setor industrial, as automobilísticas foram as quemais lançaram mão do trabalho temporário, aliás sempre fora da legislação. 0 s trabal hadores temporários deveriam ser aproveitados apenas para substituir empregos provisórios, mas havia seções em que $20 \%, 25 \%$ ou até $30 \%$ dos operários eram temporários. Q uando 0 emprego de temporários torna-se um fator estrutural, termina por se constituir em um formidável elemento de pressão sobre os mais velhos. O s jovens querem um emprego fixo e sabem que cerca de $10 \%$ deles vão ser contratados, portanto farão o possível para ganhar o reconhecimento do chefe de equipe. $0 \mathrm{~s}$ mais velhos, claro, acham que os temporários fazem pouco do trabal ho, não respeitam a antiga solidariedade operária, são puxasacos. É uma lógica que irá deteriorar as relações entre as gerações, mais ainda conforme a situação se prolonga no tempo ${ }^{9}$.

Jean -Pierre Faguer - Vocêfala da desmoralização do mundo operário e mostra que não se trata apenas de uma questão subjetiva, mas de um conjunto de mediações que dizem respei to ao papel da escola, àsaspir rações dasnovas gerações em relação aos postos de trabalho, às novas tecnologias. Então, a pergunta que gostaria de fazer é a seguinte: esses jovens mais bem formados, que saíram do ensino técnico nos anos de 1980-1990, não poderiam reagir de outra maneira? Será que não estavam desocados, pisando em falso, numa situação difícil em relação ao futuro quelheséapresentado? Por que elesnão se politizaram, por que não desenvolveram uma consciência coletiva de luta? Talvez seja uma quesão um pouco ingênua, masacho importantesuscitá-la.

Pialoux - A resposta já foi dada: eles não se sentem solidários. Q uando a gente discute com esses jovens, quando evoca o tempo longo da história, claro, eles aderem à idéia da solidariedade. M as na prática, no concreto, eles se sentem muito distanciados dos mais velhos, tanto do ponto de vista de seus interesses como nas maneiras de pensar. Além do mais, a partir da idéia de solidariedade, o que se pode propor efetivamente? Esperar? D efender a situação dos mais vel hos que, na verdade, enfrentam condições de trabalho muito duras, têm problemas graves de saúde, têm doenças profissionais, tentam o suicídio, terminam com perturbações mentais? De outro lado, não é difícil compreender por que, na lógica dos mais velhos, a presença desses jovens é insuportável. Em princípio, ninguém se opõe à idéia de
9. Esse é tema tratado por Pialoux eBeaud em "Permanentes etemporários", incluído em $\mathrm{A}$ miséria do mundo (op. cit., pp. 308-321). 
solidariedade. M as, na prática, as coisas não funcionam assim. Há uma animosidade que vai sendo criada em torno de fatos pequenos, de detal hes no cotidiano da fábrica, nas diferenças nas formas de comportamento, nos hábitos, nas maneiras de pensar. Vejam, por exemplo, o que acontece em torno das chamadas para "sugestões", queéum dos dispositivos da PeugeotSochaux. O s jovens fazem sugestões de modificações nos postos de trabaIho, que não têm nada a ver com os mais velhos, que, no fundo, preferem manter um sistema de trabalho que conhecem muito bem. É uma colisão constante que por vezes termina mal. Seo rapaz tem pele escura e mora nos conjuntos habitacionais, então a coisa pode chegar no nível de agressões bastante violentas. $\mathrm{H}$ á um exemplo que pode parecer menor, mas que acho bastante interessante. $\mathrm{No}$ início dos anos de 1990, creio que foi logo após uma greve em 1988, a Peugeot colocou caixas de música nas seções. Os operários queriam música nos locais de trabal ho e as caixas de som foram colocadas, mas era a empresa que fazia a seleção do que iria tocar. M uita gente reclamou. A solução então foi colocar aparelhos de rádio nas seções, para que os próprios operários fizessem suas escolhas. $M$ as eles não se entendiam de jeito nenhum. O s jovens queriam ouvir raps e coisas assim, os mais velhos queriam ouvir a Rádio $\mathrm{N}$ ostal gia. $\mathrm{H}$ ouve tentativas de arranjar as coisas, mas não deram certo e, ao final, a música foi proibida. Essa história se prolongou por vários anos. M as são exemplos como esse que nos permitem ver como surgem as animosidades, como elas vão se exasperando, como o clima vai se deteriorando a ponto de criar, como eles mesmos dizem, um "ambiente apodrecido".

10. Série de quatro artigos publicada no Actes dela Rechercheen Sciences Sociales entre 1984 e 1985, comentando ereproduzindo trechos de longas entrevistas que Pialoux realizou com Corouge. O sartigosforam assinadospelosdois. A origem eosconteúdos desses artigos serão tratados adiantenesta entrevista.
Michel Pialoux e Stéphane Beaud: 0 encontro de duas gerações no trabalho conjunto de pesquisa

BEAUD - Q uando cheguei, em 1988, M ichel já havia avançado bastante no trabalho de pesquisa. M as seria preciso dizer algo sobre as razões pelas quais nós começamos a trabal har juntos. Q uando ainda era estudante, interessei-me pelo movimento sindical, mas sempre achei muito enfadonha toda essa literatura sobre "relações profissionais". Em geral, a sociologia do mundo sindical é muito institucional, muito acadêmica. Q uando li as "Chroniques Peugeot" ${ }^{10}$, lembro muito bem o quanto isso me marcou. De repente na minha frente apareciam essas figuras sociais, figuras de militantes, que eu mal conhecia. Faço parte desses economistas que fugiram da economia quando viram no que ela se havia tornado, al go muito formal e 
muito modelador. D a minha parte, nunca aceitei o modelo do homo economicus. Além disso, politicamente sou da chamada, por vezes, geração M itterrand, mas que viu a esquerda deslizar em abdicações sucessivas. Então, trabalhar com operários era uma preocupação pessoal. 0 que me interessava efetivamente era prolongar um trabal ho que havia começado no I res [Institut de Recherches É conomiques et Sociales], um instituto de pesquisa intersindical, onde havia começado a entrevistar operários, mas fui praticamente impedido de fazer isso, pois, claro, não se fala de operários em um organismo sindical [risos].

N o começo, trabal hávamosjuntos. D epois, houveuma espéciededivisão do trabalho, mesmo mantendo, o tempo todo, a prática da discussão conjunta. É preciso insistir sobrea enormevantagem detrabal har a dois. I sso quase nuncaédito da pesquisa etnográfica- em geral parecequeela éuma aventura solitária. M as o fato de trabal har a dois éfundamental. U ma das lembranças mais fortes que tenho foi quando $M$ ichel estava fazendo entrevistas com os "velhos operários", nafaixa dos 40 ou 50 anos, quelhecontavam suas vidas de militantes. Enquanto isso, eu encontrava os trabal hadores temporários em suas casas, jovens vindos de outras regiões da França, que me contavam o que depois chamei de "sonhos dos trabal hadores temporários"11: encontrar um emprego estável em Sochaux depois de meses seguidos de pequenos contratos. Q uando comentava as entrevistas queM ichel haviafeito naquelemesmo dia na parteda manhã, eles soltavam um discurso muito violento contra esses "velhos" quese percebiam como gentequetivera a oportunidadedeum emprego estável, que conseguira se arranjar na vida, mas que não se preocupava em nada com a sortedosjovens, quenão estavanem aí com eles. Eratambém um discurso anti-sindical: o sindicato Ihes parecia uma espéciedeclubereservado para pessoas que ficavam lá o tempo todo, em longas reuniões, sem se preocupar com o que estava acontecendo do lado de fora. 0 u seja, essa confrontação do trabalho que cada um de nós fazia era muito importante. N ão tínhamos um diário de campo comum, mas ao final do dia discutíamos, e chegamos a gravar muitas fitas com essas discussões. Considero isso muito estimulante, éal go muito raro deacontecer. É interessante porque nem sempreconcordávamos com tudo, havia desacordos- o quenão édito nostextos queescrevemosjuntos. Eu melembro bem desituações em queM ichel estava certo, el tinha uma experiência prévia de pesquisa que eu não possuía, e de temposem temposeleme colocava nostrilhos.

Então, não se pode abstrair o fato de que esse foi um trabalho feito a dois, dois sociólogos com relações diferentes com o mundo social, com ex-
11. Em francês, "Lerêve del'interimaire"; éo título de um capítulo de Beaud não incluído em A miséria do mundo, mas que compõe a versão original em francês. Ver Beaud, "Lerêve de I'interimaire", em Pierre Bourdieu, La misèredu monde (Paris, Seuil, 1993, pp. 349-365). 
12. Citésem francês: designação correnteparaa habitação social construída pelo governo francêsnaformadeconjuntoshabitacionais. periências políticas diferentes. Eu tenho vinte anos menos que M ichel, me politizei à esquerda de uma forma mais suave, sem passar pela extremaesquerda. D iria que aos 20 anos eu era um social-democrata, talvez ainda seja. M as há uma questão fundamental para a minha geração: o livro de Soljénitsyne e toda a crítica ao stalinismo. Aos 20 anos eu descubro os "dissidentes" russos, leio toda essa literatura. Para mim, o "PC não existia", não tinha nenhuma atração, pois estava inteiramente enfeudalizado pela U nião Soviética. M as no momento em que me lancei no trabal ho de campo, o que mais me marcou politicamente foi a irrupção de Le Pen nos anos de 1980. Para mim, a verdadeira descoberta política, um choque, que me marcou, foi a irrupção da Frente $N$ acional em 1983, em D reux. Acredito que, para M ichel, tenha sido a guerra da Argélia. Para mim, foi o momento em que vi uma parte da França se tornar racista - a expressão pode ser utilizada a partir desse momento.

Q uanto ao trabalho de campo em Sochaux, terminei por me interessar mais pelos jovens de famílias imigrantes, pois achava que eles eram mais acessíveis. Q uando fazia pesquisa nos conjuntos habitacionai ${ }^{12}$, eram eles que me procuravam, mais do que os joven s "franceses", eram eles quechegavam ao sociólogo. Q uando vou às escolas fazer al guma apresentação e abro a discussão, são eles que tomam a palavra, que têm vontade de falar, o que sempre me surpreendeu: são os filhos de operários imigrantes que falam. $\mathrm{E}$ eles querem falar não tanto de sua condição operária, mas de seu status de filhos de imigrantes e da vida nas periferias. Então, vocês podem notar que no início não havia exatamente o mesmo ângulo de aproximação, pois eu e M ichel temos disposições que foram constituídas diferentemente.

Michel Pialoux: trajetória biográfica, percursos de um pesquisador

Pialoux - N asci em uma cidade do sudoeste francês, em uma família pe queno-burguesa (meus pais tinham uma farmácia), católica e bastante conservadora, à direita. D os quatro filhos - eu tinha dois irmãos e uma irmã - , apenas eu segui a carreira intelectual. M inha irmã herdou a farmácia e um dos meus irmãos se tornou professor de letras em uma escola de Poitiers. 0 mais moço, dois anos menos que eu, seguindo o desejo de minha mãe, que era muito religiosa, começou a se preparar para se tornar monge franciscano. Fez quatro ou cinco anos de seminário, mas não chegou a seordenar. Ele era muito politizado e abandonou a religião logo depois de 1968. M as foi bastante marcado por essa experiência. Formou-se em psicologia, passou algum 
tempo no Canadá e, depois, um ano na Alemanha para fazer um curso de teologia ali. Em 1980, começou a trabalhar no M inistério dos N egócios Estrangeiros.

M eu pai era bastanteconservador, maso seu irmão, queeranotário - eeles seviam freqüentemente- tinha posições bem à esquerda, próximas da extre ma-esquerda. D urantea guerra[Segunda G uerra M undial], lutou na Resistência echegou a fazer partedos "maquis" 13 deG ers, uma cidadeno sudoeste francês, queeram bem "vermelhos", com fortepredominância decombatentes espanhóis. Eleera franco-maçom efoi candidato socialista em 1946. Portanto, havia uma clivagem quefez com quea política entrassefortementenas nossas preocupações, edesdecedo comecei a ler jornais, artigos, livros políticos. 0 fato é que a França, na década de 1950, estava marcada por agudos conflitos políticos. M al sesaía da época da Resistênciae do "petainismo"14 ejá seentrava nas guerras pós-coloniaisna Indochina eArgélia.

0 determinantenaminhavidafuturafoi, então, o fato dequeeu nasci em 1939, às vésperas da Segunda Guerra M undial. Em 1956, portanto aos 17 anos, entrei na hypokhâgn $\mathrm{e}^{15}$ deBordeaux parame preparar para aÉcoleN ormaleSuperieure, elogo fui envolvido pelos debatespolíticos. Foram trêsanos depreparação. Era 1954-1956, tempos da guerra daArgélia, queoficialmentecomeçou em 1954, efui muito marcado pelas discussõesqueentão aconteciam em torno dessa guerra. N o primei ro ano dekhâgne, eu não era simpatizante da causa argelina, mas logo em seguida balancei, depois do retorno de D e Gaulle ao poder. E balancei violentamente. Aconteciam coisas de fato terríveis naquela época, como a tortura ter setornado um sistema. $\mathrm{N}$ ão fiz 0 serviço militar porque pude me beneficiar da minha condição de estudante, mas a questão se colocava para todos nós, se era preciso ou não partir para a Argélia. M uitos de meus colegas prestaram o serviço militar lá, o que fazia com quetodos nós nos sentíssemos afetados pelo que estava acontecendo. E isso memarcou violentamente. Eu meengajei deimediato naquilo queentão sechamava "Jovem Resistência", queera o nomeoficial para o queseconhecia também como "rede Janson" de ajuda aos militantes da FLN [Frente de Libertação $\mathrm{N}$ acional], aosinsubordinados, aos desertores. I sso mexeu um bocado com minha existênciaintelectual.

$\mathrm{N}$ a época eu estava mais preocupado com a atividade política do que com qualquer outra coisa, tanto assim queno último ano esqueci de fazer a prova final. Esse foi um ano em que me envolvi inteiramente com a luta política. A gentemontava guarda na casa de professores que estavam sendo ameaçados. Vários apartamentos tinham sido explodidos na época. H avia
13. O rganização armada dos "resistentes" durantea ocupação alemã.

14. Referênciaao mare chal Pétain, chefedo Es tado francês durante a ocupação al emã. 0 termo "petainismo" evocao colaboracionismo coma Alemanha, quevigorou no paísduranteaguerra. 15. Curso de preparação para o concurso de ingresso nos cursos de Filosofia e de Ciências H umanas daÉcoleN ormale Superieure, em Paris. 
16. A O AS, O rganisation del'ArméeSecrète (O rganização do ExércitoSecreto), eraumaorga nização clandestinacriadaem 1961 por partidá rios da manutenção da presençafrancesanaArgélia. Contraaindependênciaeem defesada"Argélia francesa", promoveu inúmerosatentados eassassinatosnaFrançae naArgélia.

17. Jean-François Lyotard, filósofo que iria ganhar destaque no final dos anos de 1970 com o livro La condition postmoderne, Éditionsde M inuit, 1979 (trad. port.: A condição pós moderna, G radiva, 1989).

18. Cornelius Castoriadis, filósofo queganhou notoriedade com o livro Insitution imaginairede la société, Éditions de M inuit, 1975 (trad. bras.: A instituição imaginária da sociedade, Rio deJaneiro, Paz eTerra, 1982). um clima talvez não de guerra civil, mas aconteciam explosões quase todas as noites. Os atentados da $\mathrm{OAS}^{16}$, isso de fato existiu. Ainda guardo os documentos dessa época. Fazíamos panfletagem ao longo das estradas de ferro, sabíamos parar um trem nos pontos de bifurcação e subíamos nos vagões para distribuir panfletos. Acho que nunca falei disso antes. N ão havia nada de heróico nesses atos, mas o fato é que vivíamos um clima muito intenso. No dia da independência da Argélia, em 1962, fui convidado, junto com outros, a uma reunião em Paris, na casa de militantes próargelinos. Era a primeira ou segunda vez que eu ia até Paris e passei o dia todo com os argelinos, o que era uma coisa bastante rara para os franceses na época.

Assim, esse mundo dos estudantes da khâgne exerceu a maior influência na minha vida. M uitos de meus colegas, com quem aliás mantenho ligações até hoje, tiveram um peso importante na minha vida. $\mathrm{H}$ avia formas consideráveis de mobilização contra a guerra da Argélia, todo mundo discutia muito 0 assunto, entre os alunos e também com os professores, sobretudo entre os internos, e eu também era, claro, um interno. Foi aí que comecei a ler as grandes revistas políticas: Les Temps M odernes, Esprit, as revistas do PCF, mas também as revistas críticas ao stalinismo, como Arguments e Socialisme ou Barbarie. N a época, eu fazia parte de um grupo que se chamava Pouvoir O uvrier, expressão política da revista Socialisme ou Barbarie. Era um movimento de extrema-esquerda, talvez extrema-extrema-esquerda. A revista foi introduzida por normaliens [estudantes da École N ormale Superieure], alunos de Lyotard ${ }^{17}$. C astoriadis ${ }^{18}$ eLyotard vinham fazer apresentações. Além disso, fizemos inúmeras reuniões com a "Juventude Libertária" de Bordeaux, jovens de 25 ou 30 anos, filhos de combatentes espanhóis na guerra civil e que moravam em Bordeaux.

Sergio M ICELI - M as como foi a sua decisão pela sociologia, o seu encontro com a sociologia? Ainda nos tempos da khâgne você já tinha a intenção de seguir a carreira intel ectual? Conte um pou co dessa sua relação com a sociologia.

PIALO ux - Eu sempre soube que estava destinado a ser professor. Entrei na khâgne em 1956, em junho de 1957 passei pelo I pes [I nstitut Préparatoire del'Enseignement du Second D egré] e pelo que então se chamava de propédeutique, um concurso para o ensino secundário. $M$ as, de fato, todo esse período eu estava mesmo era envolvido na luta política. C ontinuava a fazer minhas leituras, sobretudo de política ou história, mas só passei a me en- 
volver mesmo com a sociologia depois de 1966. Em 1962, entrei com uma demanda para ensinar na Argélia como Pied Rouge, como se chamavam as pessoas que foram para a Argélia depois da independência. $N$ ão sei se já se utilizava o nome de cooperação, mas na época muitos foram para a Argélia para isso, para ajudar o país. M as eu tinha um dossiêmuito pesado e ele foi recusado, o queme aborreceu tanto que resolvi deixar a região deB ordeaux delado eir embora. Encaminhei uma solicitação para dar aula na Bretanha, na Academia de Rennes, como professor de liceu em Laval. Fiquei lá três anos e militei em um sindicato do ensino secundário, em que havia muitos professores jovens envolvidos. M ilitei em uma tendência sindical que se chamava ÉcoleEmancipée, de extrema-esquerda. Foi lá que voltei a encontrar os trotskistas e passei a participar de uma organização trotskista que na época estava bastante implantada em $N$ antes e na Bretanha. Aliás, esses militantes tiveram um papel importante no desencadeamento do maio de 1968 em Saint N azaire e em N antes. Fiquei três anos nessa organização e depois me afastei, era de um sectarismo que eu achava insuportável. Aliás, foi a organização na qual também militou Lionel J ospin, na mesma época que eu. Cruzei com muita gente nessa época, um bocado de políticos franceses passaram por essa formação e todos eles foram muito marcados por essa experiência. Talvez eu não tenha sido tão marcado, pois a minha passagem pela organização foi curta e eu nunca deixei de ler autores como Lyotard e $C$ astoriadis, que havia conhecido dez anos antes. $M$ as, em certo sentido, tudo isso definiu a minha relação crítica com o PCF, com todos os que eram chamados então "stalinistas".

Em 1967, fui nomeado para 0 rléans, mas mantive contatos muito estreitos com J ean-ClaudeC ombessie, que havia sido meu colega na khâgnee entrara na École $\mathrm{N}$ ormale Superieure. Ele era muito ligado a J ean-Claude Chamboredon ${ }^{19}$, que, como ele, havia começado a trabal har com Bourdieu. D epois de um ano, consegui um afastamento do ensino secundário para preparar uma tese com Bourdieu.

Q uando voltei para Paris, resolvi romper com tudo isso, com essa época da minha vida. N ão tinha a menor vontade de rever as grandes figuras militantes que conheci nessa época, a não ser al guns colegas de Laval, com os quais tenho relações pessoais fortes, que conservo atéhoje, mas sem nada mais a ver com a organização que me parecia um monumento de sectaris mo. M as mantive relações com os trotskistas da IV I nternacional, tanto que no final dos anos de 1970, em 1977 ou 1978, passei a participar da Critique de l'É conomie Politique, uma revista fundada por gente da Liga [Liga
19. Jean-Claude Combessie e Jean-Claude Chamboredon eram colaboradores próximos de Pierre Bourdieu no Centro de Sociologia Européia. 
Comunista Revolucionária]. Ainda nos tempos de professor em Laval eu já tinha boas relações com estudantes da Liga.

Sergio M iceli - M as então como foi essa passagem do jovem militantismo para a sociologia?

PialouX - Foi em 1967 que entrei em contato com o Centro de Sociologia Européia. Antes disso, acho queem 1965, aleitura do L eshéritiers de Bourdieu e Passeron me marcou muito fortemente. 0 livro dizia respeito justamente a esse mundo estudantil muito politizado que eu havia conhecido. Acho até que o questionário de Bourdieu passou em Bordeaux quando eu ainda era estudante. Claro, Bordeaux era uma província e isso fazia uma enorme diferença em relação a Paris. M as o fato é que Bourdieu estudava as características dos estudantes de sociologia e a diferença entre herdeiros e não-herdeiros, entre parisienses e não-parisienses. I sso me dizia respeito diretamente. Além do mais, a crítica que eu então fazia de certo tipo de militantismo, a maneira como as pessoas se fechavam em questões teóricas abstratas e pseudoteóricas, isso me predisponha a acolher a temática antiesquerdista de Bourdieu e seus seguidores. Então terminei por incorporar a lógica deBourdieu. No C entro, encontrava muita gente, discutia com muitas pessoas. Foi aí que ocorreu o forte engajamento na sociologia.

Logo depois consegui um afastamento do ensino secundário para fazer a tese. Claro, fiquei sem salário. E então encontrei um trabalho de meio período na associação AideàToute $D$ étresse, que tinha sido formada por uma espécie de dama moderna de caridade, junto com o ilustre padre Joseph Wresinski, quena época, atraído pel os trabal hos de Bourdieu sobre cultura, tentou uma aproximação com ele. Era uma associação que se interessava pelo "subproletariado" e fui incorporado no quadro de um programa pré escolar financiado pela Fundação Ford, em 1967, onde fiquei um ano. 0 fato é que me envolvi bastante nesse trabalho. Eu trabal hava em Seine

20.H abitação social para o alojamento provisório de moradores transferidos recém-imigrados ou transferidos defavelas.
Saint-D enis, nas cités d'urgence [moradia social de urgência] ${ }^{20}$, o que foi uma experiência muito forte. Claro, a ideologia da associação era detestável. Com toda a minha formação trotskista, as proposições "miserabilistas" da associação eram mesmo de enfurecer, mas os lugares que 0 trabalho me levava a conhecer e as pessoas que eu encontrava, isso me marcou muito.

Em janeiro de 1969, comecei a dar aula como assistente em sociologia naSorbonne, ParisV. Entrei graçasa ean-ClaudeC ombessiee Lewandowski, que também havia sido normalien. Foi uma pressão dos assistentes - na 
época não existia ainda essa categoria de "mestre assistente" -, que defendiam a mudança nas formas de recrutamento dos professores e diziam que era preciso incorporar gente que pesquisava as classes populares, que se interessava por temas que não fossem estritamente acadêmicos. Era ainda 0 contexto de 1968 e eu terminei por me beneficiar disso, aliás para minha grande surpresa, pois de fato não esperava.

N essa época, já eraligado ao C entro deSociologiaEuropéia eminha relação com Bourdieu estava bem estabelecida. M as as minhas atividades deensino ocupavam a maior partedo meu tempo. Além disso, estava preocupado em avançar a pesquisa quehavia então iniciado paraa minha tese, sobreo tema das frações pauperizadas da classe operária na França, um assunto que eu havia começado a estudar em 1967, quando ainda estava envolvido naAideàToute D étresse. Enfim, era uma pesquisa sobre a gestão do pauperismo nas cités d'urgence, o queéuma maneira simplificada de definir as coisas, pois defato, em sua maioria, as populações que moravam nesses lugares eram categorias pauperizadas da classe operária. $\mathrm{N}$ a época não era um tema levado a sério. D epois, nosanosde1980 e1990, ganhou importânciaeum reconhecimento cada vez maior. N aquelemomento só sefalava de "operários", não de "pobres". $M$ as eu achava queera uma questão quemerecia ser vista com maiscuidado, e queria compreender melhor o quese passava nesses conjuntos habitacionais. 0 fato é que tudo isso me parecia bastante interessante. Eu discutia essas questões com Bourdieu, que aprovava e me encorajava, um tanto de longe, poisnadadisso estavano núcleo de suas preocupaçõesna época.

Jean -Pierre Faguer - Os artigos que você escreveu na época tratavam dos temas dessa pesquisa?

Pialoux - D e fato, esse foi o tema do meu primeiro artigo publicado, em 1979, com o título "Jeunesse sans avenir et travail interimai re" [Juventude sem futuro etrabalho temporário], na revistaA ctes dela Rechercheen Sciences Sociales (n. 26-27). D epois, junto com Bruno Théret ${ }^{21}$, escrevi um longo artigo, "État, classe ouvrière et logement social" [Estado, classe operária e habitação social], publicado em duas partes na Critiquedel'ÉconomiePolitique (1979, n. 9; 1980, n. 10).

SERGIo M ICELI - Q uer dizer então queessa pesquisa preparou o queveio depois? Todo esse tempo você amadureceu uma problemática, uma abordagem, uma maneira de ver as coisas.
21.Bruno Théret é atualmente diretor de pesquisa do CNRSIRIS. 
22. Instituto $\mathrm{N}$ acional deEstatística eEstudos Econômicos, o equivalente francês ao IBGE no Brasil.
PIALoux - 0 trabalho sobre Sochaux não teria sido o mesmo sem toda essa reflexão anterior sobreeconomia, sobre as práticas de trabal ho, sobrea escolarização, sobre o ensino profissional. Aliás, todos temas bourdieunianos. M as, no geral, Bourdieu não se interessava muito pelo trabalho operário. D e minha parte, eu trazia de minha herança marxista o interesse por tudo isso e sempre achei que eram temas importantes. D epois, quando cheguei em Sochaux, tudo apenas se reforçou a partir do que as pessoas me contavam sobre o trabalho na fábrica, o que acontecia na empresa, a relação com as chefias, as formas de resistência. $M$ as esses temas de fato não eram tratados no mundo de Bourdieu.

$M$ as antes de Sochaux participei por dois ou três anos em uma grande pesquisa na cidade de Amiens, da qual Jean-PierreFaguer também fez parte. Foi uma pesquisa coordenada por Bourdieu, que envolveu vários pesquisadores do C entro, desenvolvida junto com o IN SEE [Institut $N$ ational de la Statistiqueet desÉtudesÉconomiques] $]^{22}$. Erauma preocupação de Bourdieu associar a pesquisa sociológica ao trabalho estatístico, e pelo IN SEE a pesquisa era levada por estatísticos importantes, como Alain D esrosière e $M$ ichel G ollac. D a minha parte, sempre achei um tanto complicado trabaIhar com os estatísticos, pois havia diferenças de abordagem, de concep ção de pesquisa etc. $M$ as, apesar disso, escrevi um artigo junto com D esrosière, "Rapport de travail et gestion de la main-d'oeuvre" [R elação de trabalho e gestão da mão-de-obra], publicado também na Critique del'ÉconomiePolitique, em 1983. Porém, acabei me afastando por problemas de saúde. Aliás, por uma série de razões a pesquisa não foi muito em frente. $M$ as cheguei a realizar muitas entrevistas e a escrever textos sobre o mundo operário de Amiens. Trabalhei sobre três grandes fábricas de pneus na cidade. Era um material bastante interessante e isso de alguma forma me preparou para entrar no mundo de Sochaux, ganhei familiaridade com as questões da organização fabril e também com todo um vocabulário que me ajudou imensamente nos meus primeiros contatos com Corouge.

Chegando a Sochaux: o tema do trabalho e da condição operária na contracorrente dostempos

VERA T ELLES - Como foi que vocêchegou a Sochaux? Como foi o seu encontro com Christian Corouge?

Pialoux - Parte dessa história eu conto no primeiro artigo da série 
"Chroniques Peugeot", que saiu no Actes dela Rechercheen Sciences Sociales [n. 52-53, 1984]. Foi por meio de Bruno Muel e Francine Muel23, que conheceram Christian Corouge no início dos anos de 1970, quando M uel chegou a Sochaux com uma proposta de "cinema militante", que agregava jovens cineastas e intelectuais ${ }^{24}$. 0 grupo foi formado em 1967, bem no clima de efervescência que iria desembocar em 1968. Eles chegaram em Sochaux em 1970 e por quatro anos houve uma forte atividade conjunta com os militantes operários. Corouge participou intensamente e teve uma presença importante nos três filmes rodados ali entre 1971 e 1974.

Poisbem, Francine, quetambém era pesquisadorado C entro deSociologia Européia e trabalhava comigo na pesquisa sobre as cités d'urgence, falava muito das pessoas queela havia conhecido em Sochaux esobretudo em certo Christian Corouge. Insistia muito queeu iria gostar de conhecêlo, pois era, dizia ela, um tipo excepcional. M eu primeiro encontro com Corougefoi em 1981, na casa de Francine, quando então conversamos horasseguidas sobreas condições detrabal ho, o que estava acontecendo na Peugeot-Sochaux, a re pressão anti-sindical daqueles anos. D epois, em 1983, outro encontro, quando Corouge veio a Paris como delegado sindical para reuniões denegociação com a direção da empresa. Elejáhavia comentado na primeira ocasião que tinha um projeto de escrever algo, de elaborar e refletir sobre sua expe riência. Foi daí que surgiu a idéia de um trabalho conjunto com base em entrevistas gravadas. D e fato, achei realmente formidável o modo como ele falava das coisas que se passavam em Sochaux. Propus outro encontro para uma conversa gravada, e foi então que Corouge me convidou para ir a Sochaux. Elemedisse: "Vocêfica oito diassequiser, levaum gravador eeu te conto tudo o quevocêquiser". Eu fui. Voltei um mês depois. Foi assim quea pesquisa em Sochaux começou. 0 ponto de partida foi uma série de longas entrevistas com Corouge, durantetrêsanos. Elecolocava questões realmente nevrálgicas, quemelevavam a refletir sobreo queestava acontecen do no ambiente operário. Foi sobretudo por meio dele que pude compreender essa oposição entreos $0 \mathrm{~S}$ eos $\mathrm{O}$ P. Eram questões queesclareciam a crisedo sindicalismo, questões de fundo que não tinham a ver tão simplesmente com as disputas políticas do PCF e outras nesse plano. Essas questões tampouco eram tratadas pelos sociólogos, pelos especialistas em história sindical ou pelosmilitantes políticos. Corougeeraum operário qualificado, um excelenteprofissional, etinha proposições quevinham dalógica do velho militantismo operário comunista. $M$ as ele trabal hava como $0 \mathrm{~S}$ etinhaum posicionamento pertinente às questões dos operários da linha de montagem e que
23. Francine M . D reyfus, hojediretora deestudo naEH ESS, École des $\mathrm{H}$ autes Études en Sciences Sociales, também pesquisadora do Centro de Sociologia Européa.

24.Trata-se do grupo M edvedkine (19671974), nomeem home nagem a Alexandre $M$ edvedkine (19001989), cineasta soviético inventor do "cinema trem", que atravessou a União Soviética em 1932 parafilmar operá rios, camponeses e mineiros. Em 1967, um filme sobreos trabalhadores da Rodhia, em Besançon, que haviam feito uma grandegreve no ano anterior, lançou o grupo. Esteeosoutros filmesquese seguiram, projetados em circuitos alternativos e festivais, foram matériadereportagens e debates. Em Sochaux, elesbuscavam 0 encontro militante com os operários daPeugeot, protagonistas de uma então já lendária greve em 1968, acompanhada por violentos enfrentamentos com a polícia. A partir de 1999-2000, no bojo de um renovado interesse, naF rança, pela relação entrecinemadocumen- 
tário emundo operário, a experiência dessegrupo vem sendo recupera da, com reportagens na imprensaeem revistases pecializadas, e sessões especiais de projeção de seus principais filmes. Em 2006, por ocasião deuma programação da Cinemateca francesa, foi lançado o DVD "Les groupes M edvedkine" (EditionsM ontparnas se).

25. O rganismo interministerial de planejamento quefinancia pesquisaseconômicasesociais. trabalhavam em situações muito duras, enfrentando problemas que não eram levados em conta pela militância O P. C orouge faz parte da geração de 1968, chegou em Sochaux em setembro-outubro desseano efoi marcado por todo esse período. Em 1968, Sochaux viveu acontecimentos deuma extraordinária violência. Foi a única fábrica em que houve enfrentamentos entre operáriosepolícia, com operáriosmortosedezenas deferidos, o quemarcou toda a região. D epois, o quecaracterizou a história da fábricafoi umarepressão anti-sindical muito violenta, queatingiu tanto aCG T como aCFDT. Ao longo dosanos de 1970, Corougefoi envolvido por essa dinâmica, edepois, no início da década seguinte, por toda a situação que afetavaa realidadeoperária. Foi justamente por meio dessas entrevistas que passei a refletir sobre a condição operária nessesanos.

Jean -Pierre Faguer - M asqual foi a origem das "Chroniques Peugeot", como foi quevocêdeci diu publicá-lasna revista Actes?

Pialoux - Isso foi em 1983. U m pouco por acaso cruzei com Bourdieu, que me perguntou o que eu estava fazendo na época. Eu contei dessas minhas entrevistas com Corougeeeleme propôs escrever al guma coisa para a revista, sem nem mesmo ter lido um fragmento detexto quefosse. N o começo, quando cheguei a Sochaux, não tinha ainda idéia do queisso haveria de setornar, foi algo inteiramentefora da lógicauniversitária, quetinha aver com ostemas que me interessavam, mas eu não tinha a menor intenção de fazer disso um trabal ho acadêmico, com artigos, livros, coisas assim. M as, conforme as entrevistas progrediam, Corouge terminou por se envolver intensamente no trabalho. Achei então quenão faria o menor sentido enão seria honesto com Corouge continuar a realizar as entrevistas apenas pelo prazer de tê-las registradas em meu gravador. Era preciso dar algum peso a esse trabalho, conseguir um financiamento para organizar o material, publicar al guma coisa. Um dia, comentando sobre essa situação, o pessoal da Critique de I'ÉconomiePolitiquesugeriu queeu procurasseo Comissariat au Plan ${ }^{25}$, com o qual eu poderia conseguir um financiamento. I sso meobrigaria a um trabaIho maissistemático, mastambém permitiria dar reconhecimento ao próprio C orouge, quepoderia então dizer quehaviafeito essetrabal ho para o C omissariat au Plan junto com um sociólogo. E foi assim queas coisas aconteceram. $M$ as tudo isso sem que eu tivesse nem mesmo falado do assunto com Bourdieu. Q uer dizer, quando falei desse trabal ho com Bourdieu, elejá estava em curso, e logo depois Ihe entreguei o material escrito. Foi essa a origem das 
"C hroniques Peugeot", a série de quatro artigos quesaíram narevista Actesde la Recherche. 0 sartigosforam assinados por nós dois, Corougeeeu. Bourdieu sempremeperguntava quando eu irialançar o próximo artigo, meincentivou a continuar mesmo depois de a série ter se encerrado, sempre me deixava recados no tel efone. Ainda tenho comigo os recados escritosqueele me deixou no escritório.

Vera T elles - Seria interessante saber também um pouco mais sobre como 0 tema do trabalho ea chamada crise do trabalho foi sendo construída, etambém a abordagem que você desenvolveu em Sochaux. 0 interessante em tudo o que você conta é uma trajetória sempre na contracorrente das tendências predominantes na sociologia.

Pialoux - D esde meu primeiro artigo sobre o trabalho temporário, eu já levantava essas questões. N osanos de 1970, quando desenvolvia essa pesquisa sobre as cités d'urgence, as formas desval orizadas de habitação social que, na época, eram destinadasàqueles então chamados de "inadaptados" ou de "excluídos", já refletia sobre as formas de trabal ho dessa população. Para mim, eram operários, operários pauperizados. Toda aminha história fazia com que eu visse os moradores desses conjuntos habitacionais como operários e eu interrogava essas situações a partir das reflexões de Bourdieu sobreo subproletariado argelino, etambém a partir das reflexõesqueFoucault estava desenvolvendo naépoca sobreas prisões eosasil os. I sso melevavaa conferir importância ao que acontecia no plano da vida familiar e doméstica, no plano da moradia, da escola. M as também fazia com que não me interessasse pelo trabal ho nafábrica, justamentenessemomento, nos anos de 1970, em quea intelligentzia francesa privilegiava a fábrica. Eu estava mais interessado em compreender o modo como sefazia a gestão social nessas instituições deassistência e de distribuição de moradia social. N essa época eu trabalhava com Francine M uel, fizemos muitas entrevistas juntos e chegamos mesmo a dar início a uma reflexão conjunta nessa direção. Tudo isso me parecia especialmente interessante, ainda mais porque ia contra um marxismo simplista e economicista queentão predominava. Eu não tinha nenhuma afinidadecom essas pessoas que - era a época dos établis ${ }^{26}$ - privilegiavam apenas o que ocorrianas fábricas, no plano das "relações de produção".

O paradoxo é que, nos anos de 1980, quando o tema do trabalho na fábrica sai do foco das atenções, quando ninguém mais se interessava pelo queocorria noslocais de produção, aí então comecei a me interessar. 0 fato
26. Literalmente, estabelecidos: eraadesignação para os intelectuais, sobretudo estudantes, que seintegravam nasfábricascomo operáriospara desenvolver o "trabalho político". 
é que eu comecei a me interessar por aquilo que Corouge me contava do trabalho na fábrica, exatamente no momento em que já se anunciava um forte recuo nas preocupações sobreo tema do trabalho. Foi justamentenesse momento que comecei a meinteressar pela linha de montagem. D e fato, com isso, pude acompanhar de perto transformações importantes que estavam acontecendo naquele momento no chão defábrica: a informatização, 0 fluxo contínuo, a flexibilização dos contratos etc.

Q uando cheguei a Sochaux, foram três anos de entrevistas com Corouge. Em 1985, a direção da Peugeot resolveu "modernizar" a fábrica e pude acompanhar o que mudava na vida operária com as novas formas de organização do trabalho. Foi nesse momento que passei de fato a me debruçar sobre o trabal ho operário e sobre aquilo que a sociologia do trabalho poderia me dizer. Toda a questão da produção - o que $\mathrm{M}$ arx chama de laboratório da produção - esua relação com a vida social, tudo isso passou definitivamentea fazer parte do meu campo de visão. N osanos de 1970, as questões queeu me colocava eram mais propriamente questões da sociologia urbana. A liás, nesses anos, eu dava aulas de sociologia urbana na universidade. Depois, na década de 1980, foram as questões do trabal ho que passaram a me interessar. $N$ ão que eu fosse um apaixonado pela sociologia da empresa, mas passei a ler sobre o que ocorria em torno das inovações tecnológicas que transformavam a fundo o mundo da empresa e das relações de trabalho. $M$ as também é verdade que fui muito influenciado pelas análises de Bourdieu e Passeron sobre o sistema escolar e o seu lugar nas nossas sociedades. E me parecia que essas análises tinham uma incrível pertinência para dar conta do que estava acontecendo em Sochaux nos anos de 1980. Q uando comecei a trabalhar com Stéphane Beaud, era evidente para mim que seria importante abordar essas questões do ensino profissional e do papel da escola ao lado das questões relativas à organização do trabalho. Para mim estava claro que havia ali um campo de pesquisa a ser desenvolvido.

Violências urbanas: voltando atrás para compreender a atualidade

Vera Telles - Talvez seja interessante falar um pouco do livro Violences urbaines, violence sociale. É um livro escrito na seqüência deuma revolta urbana que aconteceu na região de Sochaux em 2000, mas que se inscreve em uma experiência de pesquisa de longa duração. Contudo, trata-se de outro momento do mundo operário. Vocês di scutem a relação do raci smo no meio operário com essa situação que definem como "o mundo operário após a classe operária". 
Pialoux - No último capítulo do Retour sur la condition ouvrière, tratamos da questão do racismo no meio operário. 0 fato éque o racismo não chega a aparecer tanto entre os velhos operários, franceses ou imigrantes, que se conhecem de longa data, por vezes juntos 25 anos na linha de montagem, partilhando experiências comuns (de trabalho, de lutas, de resistências cotidianas). É fora da fábrica que o problema irá aparecer no correr dos anos de 1990. H á muitos aspectos a considerar, mas o que se pode dizer aqui, simplificando um pouco as coisas, é que os mecanismos que regulam, na fábrica, as relações entre "franceses" e "imigrantes" não são mais atuantes. Aliás, o problema não vai surgir propriamente com os imigrantes, mascom os filhos de famílias imigrantes, eas relações irão se exasperar em torno das formas como uns e outros cuidam da formação dos filhos, de hábitos, de práticas que dão margem a provocações que podem evoluir rapidamente para o insulto racista.

H áum ponto importantea ser bem esclarecido: 0 que freqüentementeé consi derado como imigrantes são na verdadefilhos defamílias imigrantes. É outra geração. São jovens de famílias imigrantes que têm, na sua maioria, nacionalidadefrancesa. M esmo aquelasfamílias queforam embora em 19831984, tinham filhos nascidos na França, ecentenas deles voltaram nos anos 2001-2002, porque a situação na Argélia estava particularmente difícil. Com a nacionalidade francesa, podiam entrar em território francês, eforam empregados pela Peugeot como trabal hadores temporários. Então, nos anos de2000, o que importa são esses filhos de famílias imigrantes, etambém as filhas. $N$ osanos de 1980, seriainimaginável encontrar meninas trabal hando nalinhademontagem, a presença das mulheres era muito pequena. $M$ asnos anos de 2000 são as meninas que trabal ham nos setores de montagem.

D epois da publicação de Retour, fizemos dezenas de debates sobre a questão operária, fomos convidados a real izar essa discussão em vários lugares. Esquematizando um pouco, eu diria que os únicos que tomavam a palavra nesses debates eram os jovens de famílias imigrantes ou então as mulheres, e eles diziam: "Já que vocês dizem que os operários não tomam a palavra, pois então nós vamos falar". E selevantavam para dizer que nós não tínhamos de fato tratado da questão das mulheres ou então que não tínhamos anali sado suficientemente o problema dos jovens de famílias imigrantes. Situações como essas nos levavam a perceber que havia pontos nevrál gicos a serem ainda trabal hados.

Retour foi publicado em 1999. Em 2000 voltamos ao trabalho de campo para desenvolver uma pesquisa financiada pelo M inistério da E ducação 
sobre os jovens que trabalhavam e estudavam em escolas de ensino profissional, que oferecem certificados muito desval orizados e onde praticamente só se encontram jovens de famílias imigrantes. Em julho estoura a rebelião na região deSochaux. 0 quenos chamou a atenção nessa rebelião foi o fato de ela ter acontecido em um momento de retomada de crescimento econômico, em que esses jovens estavam conseguindo, pela primeira vez em dez anos, voltar ao mercado de trabalho, como temporários, claro. D aí o tema de uma rebelião paradoxal, que surge no momento em que há uma forte retomada do trabalho. Vimos essa rebelião acontecer e quando voltamos, alguns meses depois, em setembro, decidimos pesquisá-la. Começamos a refletir sobre o tema e chegamos a escrever um artigo com o título "Émeutes urbaines, émeutes sociales" [Le M onde D iplomatique, julho de 2001]. Percebemos que havia ali um fio vermelho para continuar a pesquisa em Sochaux, retomando nossos trabalhos anteriores para situar o que então estava acontecendo. É preciso voltar atrás para explicar o que havia se passado nessa rebelião e é justamente isso que nos dava o elo para apresentar as questões novas que então estávamos pesquisando.

Eu estava pesqui sando sobre a Technoland, as empresas de subcontratação que empregavam apenas mulheres ejovens, e também sobre o bac profissional e os jovens de famílias imigrantes que chegavam à faculdade. Então, fomos construindo aos poucos o plano desse novo livro, tomando como ponto de partida essa revolta. Achávamos que ela colocava em cena questões nevrálgicas.

D e fato, três anos depois se confirmou que a questão da rebelião urbana era um bom tema com que enfrentar o problema dos jovens de famílias imigrantes. Vimos como as pessoas procuram dar conta dos acontecimentos de 2005: ou se volta atrás para compreender os fatos recentes, ou se fica à mercê do que os jornais dizem e a tel evisão mostra... 